\title{
Comparative Economic Performance and Stock Market Performance: Some Evidence from the Asia-Pacific Region
}

\author{
Sayeeda Bano \\ The University of Waikato, Hamilton, New Zealand \\ E-mail: sbano@waikato.ac.nz
}

\begin{abstract}
Sriya Kumarasinghe (Corresponding author)
Department of Accountancy and Finance, School of Business, University of Otago

P.O. Box: 56, Dunedin 9054, New Zealand

E-mail: sriya.kumarasinghe@otago.ac.nz
\end{abstract}

Yih Pin Tang

The University of the South Pacific, Suva, Fiji

E-mail: tang_y@usp.ac.fj

Received: June 15, 2011 Accepted: November 24, 2011 Published: December 1, 2011

doi:10.5296/ajfa.v3i1.716 URL: http://dx.doi.org/10.5296/ajfa.v3i1.716

An early version of this paper was presented at the 27th annual conference of Euro-Asia Management Studies Association (EAMSA) held in Delhi, India, in November 2010. The authors wish to thank the two anonymous reviewers and the Conference participants for their valuable comments. They also wish to thank the University of Otago and the Department of Accountancy and Finance for the Bloomberg facility. Special thanks go to Mr. Warren Bailey, Dr. Shawn Strother, and Professor Timothy Crack for all their help and constructive suggestions. We also extend our thanks to the University of Waikato for EAMSA Conference participation support and Professor Jose Tabbada for his valuable comments. Any errors and omissions are our own.

\section{Abstract}

This study looks at interdisciplinary research in the fields of economics, finance and socioeconomic relations addressing the question whether the ranking of countries by major 
economic, social, and financial performance indicators provide any guide to the rate and pattern of growth and development in the Asia-Pacific region. The paper also examines the extent of balanced and sustained growth in selected 14 Asia-Pacific countries. It analyses data on MSCI returns, GDP growth, and HDI to rank and correlate the overall performance of each country during the 1993-2009 period. Gini Index and CPI are also included to provide added insights. The results show that developing countries like India, Indonesia, Pakistan, and Sri Lanka are at the top on most of the financial and economic indicators, while Japan is the lowest except on HDI, where the bottom rankings goes to India, Indonesia and Pakistan. Overall, the results indicate no significant relationships between a country's stock market returns and its GDP growth. Nonetheless, the results suggest that for balanced and sustainable well-being, economic growth in the less-developed countries need to be matched by concomitant improvements in social welfare, income distribution, transparency and accountability.

Keywords: Performance ranking, HDI, Stock market, Asia-Pacific, Sri Lanka

JEL Classification: F010, F040, E44, E63, F14, F15, O057, R11. 


\section{Introduction}

Nations comprising the Asia-Pacific region are a diverse group with different historical backgrounds, religious beliefs and affiliations, and socio-cultural practices. They also have different levels of economic development, rates of economic growth and capital market performance. Nonetheless, these nations have experienced rapid growth and rising levels of income over the past several decades. Their economic growth as well as capital market performance has been aided largely by the rapid expansion of multinational enterprises and the integration of international financial markets which are characteristic of the current phase of globalisation. This in turn has resulted in significant increases in international capital inflows and outflows in the region. According to the latest indicators on economic and human development from the International Monetary Fund (IMF), more than any other region, Asia is making a stronger contribution to the global recovery from the current recession. This is in large part due to the strong domestic demand in these Asian countries, which has been due to the rapid economic growth experienced by these countries in the decades prior to, as well as after, the Asian financial crisis of 1997. The East Asian countries have been favoured recipients of Foreign Direct Investments (FDIs), or have had high levels of foreign trade or both as a consequence of the rapid growth in their economies. Another contributing factor was the significant growth in business activities between and among the neighbouring countries in the region.

Although there are previous studies which looked at the relationship between macro-economic variables and stock market prices (Lee, Boon and Baharumshah, 2001; Fifield, Power, and Sinclair, 2002; Patro, Wald, and Wu, 2002; Gunasekarage, Pisedtasalasai, and Power, 2004; Wickramasinghe, 2011), it is our understanding that studies on stock market performance and social performance are rare or almost non-existent. Having a meagre attention on social performance creates a big gap in this research field, because as countries advance economically and financially, the improvement in peoples' welfare cannot be ignored or postponed. Given the financial and economic importance of Asian countries in global trade and investment, an investigation of the financial-economic performance and social performance in these countries is both necessary and timely.

The aim of this paper is thus to examine the relationship between financial and economic performance on one hand, and social performance on the other. The study also attempts to explore the extent to which these countries have been able to maintain balanced and fairly sustained growth during the period 1993-2009. Sri Lanka is examined as a special case of a country which has managed to achieve continuous economic growth despite a long-running and destructive war with extremists.

Economists generally use macroeconomic indicators to evaluate a country's economic performance, while financial analysts employ financial market data to assess its financial strength. The two indicators (macro-economic and financial) are seldom combined in one study. This paper attempts to combine economic, financial and social indicators to rank a sample of countries according to their growth and development performance. It examines the movements of stock prices and socio-economic performance to determine whether and (if 
so) to what extent the two are related. By enhancing our knowledge and understanding of the co-movements and correlations of these indicators, the findings of this study intend to enhance the usability of such indicators to investors and policymakers alike.

The outline of the paper is as follows. The first section reviews the recent literature on stock market and economic performance, and emphasizes the significance of social performance for people's well-being in a country. The second section discusses the methodology and the data used for the study. The third section reports the results and analyzes their implications. The last section presents the conclusion, the limitations of the study, and possible future research.

\section{Literature Review}

\subsection{Macro-economy and the equity market}

One of the major goals of open economies is to have sustainable economic growth. Development theory suggests that indices such as GDP, per capita GDP, literacy rate, poverty level, Gini Index (for income distribution), and level of corruption signify the level of "well-being" of a particular country. On the one hand, the economic growth and efficiency of a country largely depends on the country's financial system, in which the stock market contributes to economic growth via productive investments. On the other hand, stock market performance is often used as a general gauge of a country's business environment. This is so because performance in the share market reflects or is affected by such factors as rate of inflation, interest rate, levels and rates of growth of disposable incomes, trade balance, and the degree of transparency and accountability in the economy.

The performance or success of an economy is often indicated by: a) economic growth, b) efficiency, c) income distribution, d) stability, and e) viability. Gregory and Stuart (2004) call these as "performance criteria". In the development literature, these criteria are often subsumed under the rubric of "development", which is much broader concept than mere economic growth. Rosser and Rosser (2004) came up with a more detailed set of nine criteria $^{1}$ that can nevertheless also be subsumed under the five criteria proposed by Gregory and Stuart (2004), so our discussion focuses on the latter.

Economic growth refers to the level and rate of growth of output and income, total as well as per capita, and the composition of output over time. Efficiency, on the other hand refers to the relationship between output and the inputs used in producing that output, and efficiency is often indicated by the presence (or absence) of economies of scale, total factor productivity, and the absence of corruption. Efficiency is related to growth in the sense that efficient economies are likely to grow more rapidly than those that are not, and such economies are expected to have no or lower level of corruption.

\footnotetext{
${ }^{1}$ Nine Criteria (Rosser and Rosser, 2004): The level of output (GDP of an economy); the growth rate of output, adjusted for population growth; per capita GDP; composition of output; static and dynamic efficiency; macroeconomic stability (inflation and employment); economic security of the individual; the degree of equity of the income and wealth distributions (Gini Index); the degree of freedom available to the individual and Human Development Index (which is constructed from real per capita income, life expectancy, adult literacy rates, and education enrolment).
} 
Corruption is increasingly recognized in the development literature as a major obstacle to growth and development. Corruption, usually indicated by the Corruption Perception Index, (CPI) distorts the allocation of resources by channelling them to inefficient projects, wastes scarce societal resources on the unproductive activity of "rent-seeking”, and generally increases transaction costs. Although there is no one-to-one negative correlation between the level of corruption and the rate of economic growth (some corrupt countries have grown while others have stagnated), a strong case can be made that growth, income levels and income distribution could have been higher or better with lesser corruption.

As economic growth, or in other words, rate of increase in output, how output is distributed among the various income groups or classes is also important. Most countries have as their stated objective an equitable distribution of income, which is usually measured by the Gini Index. Policymakers of developing countries are acutely aware of "Kuznets' inverted U-shaped curve", according to which income distribution worsens during the early stages of industrialization, and are determined to escape the operation of this "iron law". Some countries have been more successful than others in escaping Kuznets' curve and among the more successful ones have been the East Asian "tigers", in which rapid economic growth has come hand-in-hand with a relatively equitable distribution of income. Most countries have not, however, been so fortunate.

Stability refers to macro-economic stability, which is usually indicated by low inflation and interest rates, low levels of unemployment and underemployment, a balanced budget, and other "fundamentals" of good economic housekeeping. These are important not only in and of themselves, but also in providing a conducive environment for business. Broadly defined, stability can include political stability in the sense of peaceful handover of power, and policy continuity. Abrupt policy reversals or changes in the "rules of the game" such as a decision of a new government to cancel all the contracts entered into by the previous government would hinder the expected stability of the economy.

Viability is, in our view, more or less the same as sustainability, defined, as in environmental economics, as leaving the future generations at least as well off as the present generation. It means not depleting the capital stock but maintaining it or even adding to it. It also means not saddling future generations with unsustainable deficits and debt burdens.

An increasingly important measure that captures many of the foregoing and focuses more on the human aspect is the Human Development Index (HDI). HDI encompasses indicators of well-being such as health, nutrition, infant and maternal mortality, education, environment, security and other factors that positively contribute to the realization of the full human potential. HDI correlates well with levels of per capita income. Although countries with high levels of per capita income score or rank high in HDI, the correlation would not be perfect (Gregory and Stuart, 2004). Alvan (2009) has conducted an empirical test using 90 countries including both developing and developed nations which confirmed a negative correlation between high HDI and income inequality as well as a positive correlation between medium and low levels of HDI and income inequality. Assessing how HDI correlate with market performance is a matter we investigate in this paper. 
When we relate stock market performance to socio-economic performance, we refer primarily to the foregoing criteria by Gregory and Stuart (2004). Several previous studies have linked macro-economic and stock prices for evaluating developing countries' performance. For example, the results of a previous research by Pilinkus (2009) on Lithuanian stock market support the hypothesised association between changes in the stock prices and measures of real economic activity. For instance, the mobilization of domestic savings through the stock market assists in capital formation, which is essential to a country's economic growth. Rapid growth attracts investment, which enhances stock market performance, which in turn fuels further growth, and so on, in a virtuous upward spiral. The converse is, of course, also possible. If, for whatever reason (lack of confidence usually being one), investments are withdrawn by the domestic or foreign investors, this will result in lower stock market performance, which will in turn lead to lower growth prospects or performance, and so on, in a downward spiral.

Using daily returns from 1988 to 1998, Johnson and Soenen (2002) investigated the degree of integration between Japan's equity market and the equity markets of twelve Asian countries. The results indicated that the equity markets of Australia, China, Hong Kong, Malaysia, Singapore and New Zealand were highly integrated with the Japanese market, especially since 1994. It should be recalled that during the said period Japan experienced a stagnating economy following the 1985-1990 asset price bubble. Despite this, the increased exports from other Asian economies to Japan, on one hand, and the greater FDI from Japan to Asian economies, on the other hand, increased the co-movement between the Japanese stock market and the Asian equity markets (Johnson and Soenen, 2002).

While most studies on stock market and economic performance have focused on advanced economies, Kyereboah-Coleman and Agyire-Tettey (2008) did a case study on the stock exchange of Ghana, a developing country, for the period 1991-2005, in order to examine the effects of macroeconomic indicators on stock market performance. The study showed that while high lending rates and inflation rates had a negative impact on the performance of Ghana's stock market, the resulting domestic currency depreciation still benefited the investors. In a more or less similar study, Pilinkus (2009) investigated the association between macroeconomic variables and the Lithuanian stock market index from December 1999 to March 2008. The results from this study revealed that the GDP deflator, net export, and FDI impacted on the stock market index. These study reports stimulated our interest to explore the economies in the Asia-Pacific region.

In an empirical work on a sample of 27 countries including $\mathrm{G7}^{2}$ and Southeast Asian economies, Henry et al. (2004) used switching regression analysis to examine the relationship between stock returns and growth rates during the period 1982-2001. The authors concluded that in the Organization for Economic Cooperation and Development (OECD) and in five Southeast Asian countries (Hong Kong, Korea, the Philippines, Singapore, and Taiwan) there was a significant relationship between stock returns and economic growth.

\footnotetext{
${ }^{2}$ G7 countries include France, Germany, Italy, Japan, UK, USA, and Canada.
} 


\subsection{Co-movement of economic and stock market performance}

Two explanations have been offered for the co-movement of stock markets and economies in different countries. One is that stock markets are highly influenced by global factors, in which the macroeconomic variables are closely associated. The other explanation is that there is no correlation between market returns and fundamental market information. Albuquerque and Vega (2009) attempted to verify the role of news about fundamental stock market performance in cross-country correlations between the US and Portugal, using variables such as daily stock market returns, order flow and real-time macroeconomic news release of GDP, unemployment rate, industrial production, industrial sales, retail sales, trade balance, the Consumer Price Index, and Production Price Index. The authors concluded that cross-country stock market returns were not responsive to the US macroeconomic news. However, when Portuguese macroeconomic news was released the existence of different degrees of impacts on investors' decisions was confirmed by decreasing the co-movement.

Comparative studies include either economic and financial variables or economic and socio-economic variables. Fifield et al. (2002) investigated the predictability of stock market returns through the movements of global and local economic factors, namely, GDP, inflation, money and interest rates, world industrial production and world inflation. Analyzing the data from 13 emerging stock markets over the period of 1987-1996, the authors concluded that both global and local factors were crucial in explaining stock market returns in emerging economies. Using annual data of a diversified sample of 13 countries for the period 1960-2002, Handa and Khan (2008) tested for Granger causality and reported that there was no one-way causality from financial development to economic development. According to their findings, India, Argentina, Germany, Japan, the UK and the US had a bi-directional Granger causality, while Bangladesh, Sri Lanka, Brazil, Malaysia, Thailand, and Turkey had a uni-directional causality that ran from economic growth to financial development.

Using Johansen's methodology of multivariate co-integration analysis on monthly time-series data, Gunasekarage (2004) examined the dynamic interrelations between macroeconomic variables and the stock market index in Sri Lanka. Macroeconomic variables such as the money supply, the treasury bill rate (as a measure of interest rate), the consumer price index, the exchange rate and market index data for the period January 1985- December 2001 were used for the study. Monthly values of share price index were used to represent aggregate equity returns of the market for the 17-year period. Variance decompositions analyses revealed that a major proportion of the variability in the market index was explained by the stock market's own innovations, while only a minority was explained by macroeconomic variables. The author attributed the results obtained to the fact that the macroeconomic variables used in the study represented only a subset of variables available in studies of developed markets. A recent research on Sri Lanka by Wickremasinghe (2011) confirmed the causal relationship between stock prices and macroeconomic variables such as the exchange rate, three months' deposit rate, the consumer price index and GDP.

In general, although there are a number of researches on financial and economic performance, we are not aware of any research to date that uses socio-economic variables along with 
financial and economic data. This indicates a rather narrow view of the concept of 'development'. When a country has high performance both economically and financially, are people in the country well-looked after? In other words, do improvements in economic and financial performance lead to improved socio-economic conditions? This paper attempts to answer the above question by using Morgan Stanley Capital International (MSCI) returns, the GDP growth, and HDI to examine whether these three performance measures exhibit similar rankings. In addition to this, we attempt to determine the type of correlation between the variables for any of the sample countries.

\section{Data and Variables}

\subsection{Data Description}

The sample countries included East Asian countries and a few Asia-Pacific countries where financial, economic and socio-economic data were available for the period 1993-2009. The selected group of East Asian economies were China, Hong Kong, Indonesia, Japan, Malaysia, Philippines, Singapore, South Korea (Korea from here onwards) and Thailand ${ }^{3}$. Since India is geographically close to East Asia and has experienced exceptionally high economic growth rates in recent years (making the country a popular FDI target), it was also included in the dataset. For added insights, Sri Lanka, Pakistan, Australia and New Zealand were also included in the sample.

All the stock market data were obtained from the Bloomberg data provider. MSCI index, a widely adopted benchmark for cross-border equity funds licensed by Morgan Stanley, was selected as the main financial variable in this study. Mean returns were calculated based on the yearly closing prices of the MSCI country indices.

Most of the economic and socio-economic data were obtained from the World Bank and IMF. Corruption and Gini indices have been calculated only periodically. Therefore the use of such data was limited. HDI was available continuously from the year 2005 to 2009 which enabled us to analyze the correlation during that time period.

\subsection{Ranking Approach}

For the ranking in a given year, each country's MSCI annual returns were calculated based on the yearly closing prices between two consecutive periods. For a range of sample years, the rankings were based on the mean of the annual returns for that time period. GDP growth rates were calculated in a similar way based on the country's annual nominal GDP expressed in local currencies. Countries were then ranked from highest to lowest in each category.

For the most part of the analysis, MSCI returns and GDP growth rates were the two major variables chosen to represent financial and economic variables, while HDI, Corruption and Gini coefficients were selected as the socio-economic indicators. Mean ranking and correlation analysis were the statistical methods used.

\footnotetext{
3 This study can be extended to include all other countries or regions worldwide that have established equity market indexes and periodic reports on socio-economic indicators. Taiwan was not included since the country's socio-economic data were not available through IMF or World Bank as Taiwan is not a member of these organisations. Laos, Myanmar, Vietnam and other Pacific countries were excluded due to insufficient or unavailability of data.
} 


\section{Results}

This section presents the summary statistics and performance ranking results of MSCI returns, GDP growth rates, and HDI. The analysis has two components: (1) an examination of performance rankings during the East Asian financial crisis around 1997 and the US credit crunch/global financial crisis in 2007; and (2) performance ranking on selected financial, economic and socio-economic variables.

The statistical summary is presented in Table 1. For MSCI returns, Sri Lanka has the widest range of $248.25 \%$, a standard deviation of $56.50 \%$ and a mean of $19.75 \%$. Australia has the lowest range: MSCI returns of $73.99 \%$, a standard deviation of $17.24 \%$ and a mean of $8.18 \%$. For GDP growth, Indonesia has the broadest range of $41.73 \%$, a standard deviation of $9.47 \%$ and a mean of $19.54 \%$, which is the highest among the sample countries for the sample period. Indonesia also has the highest mean MSCI returns during the sample period. In contrast, New Zealand has been more stable with the smallest range of GDP growth at 6.94\%, a standard deviation of $2.19 \%$, and a mean of $5.42 \%$.

\subsection{Performance rankings in times of crisis}

\subsubsection{The 1997 East Asian Financial Crisis}

In the 1980s and early 1990s, the "East Asian tigers” or “dragons” (Hong Kong, Singapore, Korea, and Taiwan) received attention from the rest of the world for their double-digit economic growth. Given their stellar economic performance, special attention is paid to compare performances with other countries in the Asia-Pacific during the years surrounding the 1997 crisis. 
Table 1. SUMMARY STATISTICS (1993-2009)

\begin{tabular}{|c|c|c|c|c|c|c|}
\hline & $\begin{array}{c}\text { MSCI } \\
\text { Returns }\end{array}$ & $\begin{array}{c}\text { GDP } \\
\text { Growth }\end{array}$ & $\begin{array}{c}\text { MSCI } \\
\text { Returns }\end{array}$ & $\begin{array}{c}\text { GDP } \\
\text { Growth }\end{array}$ & $\begin{array}{c}\text { MSCI } \\
\text { Returns }\end{array}$ & GDP Growth \\
\hline & Australia & Australia & China & China & Hong Kong & Hong Kong \\
\hline Mean & 8.18 & 6.42 & 6.38 & 16.14 & 6.48 & 3.64 \\
\hline Maximum & 34.06 & 9.12 & 80.27 & 35.95 & 55.38 & 8.47 \\
\hline Minimum & -39.93 & 1.55 & -52.23 & 3.63 & -53.16 & -6.03 \\
\hline Range & 73.99 & 7.57 & 132.50 & 32.31 & 108.54 & 14.49 \\
\hline \multirow[t]{2}{*}{ Standard Deviation } & 17.24 & 1.76 & 44.85 & 8.92 & 31.52 & 3.86 \\
\hline & India & India & Indonesia & Indonesia & Japan & Japan \\
\hline Mean & 19.49 & 13.32 & 23.95 & 19.54 & 0.69 & -0.06 \\
\hline Maximum & 91.51 & 17.87 & 106.47 & 52.26 & 45.69 & 2.11 \\
\hline Minimum & -56.82 & 7.70 & -50.76 & 10.53 & -43.62 & -6.12 \\
\hline Range & 148.33 & 10.17 & 157.23 & 41.73 & 89.31 & 8.22 \\
\hline \multirow[t]{2}{*}{ Standard Deviation } & 41.28 & 3.35 & 48.17 & 9.47 & 22.81 & 2.10 \\
\hline & Korea & Korea & Malaysia & Malaysia & New Zealand & New Zealand \\
\hline Mean & 15.72 & 9.10 & 10.84 & 9.43 & 3.13 & 5.42 \\
\hline Maximum & 79.15 & 18.31 & 113.48 & 18.50 & 49.43 & 8.16 \\
\hline Minimum & -44.55 & 2.01 & -51.62 & -8.70 & -42.35 & 1.22 \\
\hline Range & 123.71 & 16.29 & 165.10 & 27.20 & 91.77 & 6.94 \\
\hline \multirow[t]{2}{*}{ Standard Deviation } & 39.23 & 4.83 & 38.35 & 6.85 & 20.31 & 2.19 \\
\hline & Pakistan & Pakistan & Philippines & Philippines & Singapore & Singapore \\
\hline Mean & 18.30 & 15.02 & 11.46 & 10.79 & 10.07 & 7.24 \\
\hline Maximum & 116.65 & 30.21 & 155.11 & 14.81 & 98.99 & 16.09 \\
\hline Minimum & -68.40 & 5.77 & -46.77 & 3.64 & -49.50 & -3.98 \\
\hline Range & 185.05 & 24.44 & 201.88 & 11.17 & 148.49 & 20.07 \\
\hline \multirow[t]{2}{*}{ Standard Deviation } & 51.87 & 5.98 & 48.06 & 2.60 & 37.93 & 6.90 \\
\hline & Sri Lanka & Sri Lanka & Thailand & Thailand & & \\
\hline Mean & 19.75 & 15.42 & 9.65 & 7.19 & & \\
\hline Maximum & 187.67 & 23.25 & 115.37 & 15.34 & & \\
\hline Minimum & -60.58 & 8.64 & -51.79 & -2.24 & & \\
\hline Range & 248.25 & 14.61 & 167.15 & 17.59 & & \\
\hline Standard Deviation & 56.50 & 3.92 & 49.49 & 5.02 & & \\
\hline
\end{tabular}




\section{Al Macrothink}

Asian Journal of Finance \& Accounting ISSN 1946-052X 2011, Vol. 3, No. 1: E7

As shown in Tables 2A and 2B, all East Asian countries experienced negative MSCI returns in 1997, with Thailand registering a low $-51.79 \%$. Thailand's low ranking for the years 1996 and 1997 reflects the fact that the 1997 East Asian financial crisis started or first manifested itself in Thailand. By GDP growth, Thailand was also ranked at the bottom three in 1997 and 1998. By contrast, countries outside the region, like Pakistan and Sri Lanka, were ranked within the top three in 1997, in terms of the MSCI returns and GDP growth. Indonesia had the highest GDP growth, but it had one of the lowest ranks based on MSCI returns.

Table 2a. Performance Rankings by Msci Returns (\%) Around The 1997 East Asian Financial Crisis

\begin{tabular}{|l|r|l|r|l|r|}
\hline \multicolumn{1}{|c|}{ Country } & \multicolumn{1}{|c|}{ Country } & \multicolumn{1}{c|}{1997} & \multicolumn{1}{c|}{1998} \\
\hline China & 35.16 & Pakistan & 36.36 & Korea & 68.51 \\
\hline Indonesia & 29.55 & Sri Lanka & 21.39 & Hong Kong & 55.38 \\
\hline Malaysia & 23.86 & India & 19.94 & Australia & 10.26 \\
\hline Philippines & 17.08 & Australia & 6.60 & Philippines & 9.78 \\
\hline Australia & 6.22 & New Zealand & 1.31 & Indonesia & -2.19 \\
\hline New Zealand & 5.03 & Hong Kong & -7.62 & Malaysia & -5.60 \\
\hline India & -1.97 & Japan & -15.05 & Japan & -9.55 \\
\hline Japan & -5.47 & Singapore & -16.98 & Thailand & -16.06 \\
\hline Pakistan & -5.54 & China & -26.33 & Singapore & -16.40 \\
\hline Singapore & -9.07 & Korea & -34.34 & India & -16.42 \\
\hline Sri Lanka & -11.26 & Indonesia & -40.80 & New Zealand & -17.81 \\
\hline Hong Kong & -25.68 & Philippines & -43.82 & Sri Lanka & -19.44 \\
\hline Korea & -32.84 & Malaysia & -51.62 & China & -43.83 \\
\hline Thailand & -36.84 & Thailand & -51.79 & Pakistan & -56.06 \\
\hline Source: The MSCI mean returns were calculated based on the MSCI indexes from Bloomberg. & \\
\hline
\end{tabular}


Table 2b. Performance Rankings by Gdp Growth around The 1997 East Asian Financial Crisis

\begin{tabular}{|c|l|c|l|c|l|c|}
\hline \multicolumn{9}{|l|}{} & 1996 & Country & 1997 & Country & 1998 \\
\hline Rank & Country & 17.32 & Indonesia & 17.86 & Indonesia & 52.26 \\
\hline 1 & China & 17.17 & Sri Lanka & 15.90 & India & 14.67 \\
\hline 2 & Indonesia & 15.67 & Pakistan & 14.53 & Sri Lanka & 14.35 \\
\hline 4 & India & 15.03 & Philippines & 11.73 & Pakistan & 10.27 \\
\hline 5 & Sri Lanka & 14.05 & Malaysia & 11.06 & Philippines & 9.82 \\
\hline 6 & Palaysia & 13.96 & India & 10.77 & China & 5.97 \\
\hline 7 & Pakistan & 13.63 & China & 10.10 & Australia & 5.48 \\
\hline 8 & Korea & 12.48 & Korea & 9.48 & Korea & 2.01 \\
\hline 9 & Thailand & 10.15 & Singapore & 9.07 & New Zealand & 1.22 \\
\hline 10 & Singapore & 9.70 & Australia & 5.32 & Malaysia & 0.51 \\
\hline 11 & Australia & 6.05 & Hong Kong & 5.06 & Japan & -2.08 \\
\hline 12 & New Zealand & 4.86 & New Zealand & 3.73 & Thailand & -2.24 \\
\hline 13 & Hong Kong & 4.19 & Thailand & 2.64 & Singapore & -3.12 \\
\hline 14 & Japan & 1.99 & Japan & 2.11 & Hong Kong & -6.03 \\
\hline Source: GDP growth rates were calculated based on the nominal GDP in local currencies obtained from IMF. &
\end{tabular}

\subsubsection{The 2007 US Global Financial Crisis}

The 2007 US credit crunch was triggered by a liquidity shortfall in the world's largest economy. To a greater or lesser extent, however, the crisis also affected other countries worldwide. The rankings by the MSCI mean returns and nominal GDP growth during the period are reported in Tables 3A and 3B, respectively.

As Table 3A shows, for the year 2007 New Zealand, Japan, Sri Lanka and Hong Kong's MSCI returns were negative, ranging from $-4.68 \%$ in New Zealand to $-53.16 \%$ in Hong Kong. By GDP growth, Japan, New Zealand and Hong Kong were in the bottom three in 2007, as shown in Table 3B. Japan remained low in terms of GDP growth ranking in the next two years. Within the total sample period, Japan experienced negative GDP growth in the years 1998-1999, 2001-2003, and 2008-2009, and also negative MSCI returns in the years 1996-1998, 2000-2002, and 2007-2008. The highest MSCI return in Japan was $42.94 \%$ in 2005. 
Table 3a. Performance Rankings by MSCI Returns (\%) around The 2007 Us/Global Financial Crisis

\begin{tabular}{|c|c|c|c|c|c|c|c|c|}
\hline Rank & Country & 2006 & Country & 2007 & Country & 2008 & Country & 2009 \\
\hline 1 & China & 78.68 & China & 63.54 & Hong Kong & 55.28 & Sri Lanka & 187.67 \\
\hline 2 & Indonesia & 55.02 & Indonesia & 57.50 & Australia & -39.93 & India & 91.51 \\
\hline 3 & Sri Lanka & 50.26 & India & 52.49 & Korea & -40.62 & Indonesia & 90.27 \\
\hline 4 & India & 46.47 & Pakistan & 34.13 & Malaysia & -40.77 & Pakistan & 89.77 \\
\hline 5 & Philippines & 43.59 & Malaysia & 32.68 & New Zealand & -42.35 & Singapore & 63.02 \\
\hline 6 & Hong Kong & 37.83 & Thailand & 31.33 & Japan & -43.62 & Thailand & 63.00 \\
\hline 7 & Singapore & 30.94 & Korea & 30.80 & Philippines & -46.77 & China & 58.86 \\
\hline 8 & Malaysia & 24.25 & Philippines & 16.26 & Thailand & -48.72 & Korea & 56.63 \\
\hline 9 & Australia & 18.28 & Singapore & 16.25 & Singapore & -49.50 & Philippines & 55.79 \\
\hline 10 & New Zealand & 6.26 & Australia & 12.22 & Indonesia & -50.76 & Malaysia & 46.25 \\
\hline 11 & Japan & 6.09 & New Zealand & -4.68 & China & -52.23 & Australia & 30.84 \\
\hline 12 & Korea & 2.31 & Japan & -11.33 & India & -56.82 & New Zealand & 14.84 \\
\hline 13 & Pakistan & 0.14 & Sri Lanka & -14.20 & Sri Lanka & -60.58 & Japan & 7.25 \\
\hline 14 & Thailand & -5.87 & Hong Kong & -53.16 & Pakistan & -68.40 & Hong Kong & 6.48 \\
\hline
\end{tabular}

In 2008, Hong Kong's MSCI returns managed to rebound, while all the other sample countries suffered from deep plunges in their MSCI returns ranging from $-39.93 \%$ in Australia to $-68.40 \%$ in Pakistan. In 2008, Japan was the only country in the sample which experienced negative GDP growth rates, while in 2009 several other countries like Malaysia, Singapore, Hong Kong and Thailand also experienced negative nominal GDP growth, as shown in Table 3B.

Table 3b. Performance Rankings by Nominal GDP Growth around The 2007 Us/Global Financial Crisis

\begin{tabular}{|c|c|c|c|c|c|c|c|c|}
\hline Rank & Country & 2006 & Country & 2007 & Country & 2008 & Country & 2009 \\
\hline 1 & Indonesia & 20.36 & Sri Lanka & 21.78 & Indonesia & 25.32 & Pakistan & 24.37 \\
\hline 2 & Sri Lanka & 19.81 & China & 21.41 & Sri Lanka & 23.25 & Indonesia & 13.37 \\
\hline 3 & Pakistan & 17.28 & Indonesia & 18.32 & Pakistan & 18.10 & India & 11.78 \\
\hline 4 & China & 15.67 & Singapore & 15.78 & China & 16.85 & China & 11.54 \\
\hline 5 & India & 15.58 & India & 15.50 & Malaysia & 15.46 & Sri Lanka & 9.40 \\
\hline 6 & Philippines & 10.79 & Pakistan & 13.77 & India & 12.66 & Philippines & 3.64 \\
\hline 7 & Singapore & 10.66 & Malaysia & 11.37 & Philippines & 11.44 & Korea & 3.57 \\
\hline 8 & Thailand & 10.52 & Philippines & 10.24 & Australia & 9.12 & New Zealand & 1.68 \\
\hline 9 & Malaysia & 9.95 & Australia & 9.09 & New Zealand & 7.50 & Australia & 1.55 \\
\hline 10 & Australia & 7.65 & Thailand & 8.66 & Thailand & 6.40 & Thailand & -0.27 \\
\hline 11 & Hong Kong & 7.02 & Korea & 7.29 & Korea & 5.28 & Hong Kong & -2.66 \\
\hline 12 & New Zealand & 5.65 & Hong Kong & 6.38 & Singapore & 3.02 & Singapore & -3.27 \\
\hline 13 & Korea & 5.03 & New Zealand & 5.03 & Hong Kong & 2.15 & Japan & -6.12 \\
\hline 14 & Japan & 1.12 & Japan & 1.61 & Japan & -2.02 & Malaysia & -8.70 \\
\hline
\end{tabular}


4.1.3 Do country-specific economic, financial, and socio-economic performance indicators tell the same story in the Asia-Pacific region?

Overall, the rankings based on MSCI returns and GDP were not consistent for all countries in the sample, or for all the years. It was observed both the MSCI returns and GDP growth ranked Indonesia and China at the top, while Hong Kong and Japan were ranked at the bottom in 2007. However, Sri Lanka, which had MSCI return of $-14.20 \%$ in 2007, was ranked first in terms of GDP growth (21.78\%). This shows that the two indicators do not always provide consistent rankings or that they move in the same direction. This is because measures of a country's economic growth, such as its GDP level and rate of growth and per capita income, are determined by various factors, including a country's rate of domestic saving and investment, total factor productivity, human capital and technology, government expenditures, the country's legal and institutional framework, income distribution, level of corruption, the exchange rate regime, and the presence (or absence) of sound financial institutions and policies. These measures of economic growth in each country seem to have varying degrees of influence in their own contexts.

\subsection{Rankings Across Variables}

During the sample period 1993-2009, Indonesia, on average, topped the performance in terms of MSCI returns and GDP growth, whereas Japan was ranked the lowest under both MSCI returns and GDP growth. In terms of human development, however, Japan ranked third while Indonesia ranked in the bottom three, as displayed in Table 4.

Table 4. Performance Rankings By Msci, Gdp And Hdi For 1993-2009

\begin{tabular}{|c|c|c|c|c|c|c|}
\hline \multirow{2}{*}{$\begin{array}{c}\text { RANK } \\
1\end{array}$} & \multicolumn{2}{|c|}{$\begin{array}{c}\text { MSCI RETURNS (\%) } \\
(1993-2009)\end{array}$} & \multicolumn{2}{|c|}{$\begin{array}{c}\text { GDP GROWTH (\%) } \\
(1993-2009)\end{array}$} & \multicolumn{2}{|c|}{$\begin{array}{l}\text { HDI INDEX } \\
(2005-2009)\end{array}$} \\
\hline & Indonesia & 23.95 & Indonesia & 19.54 & Australia & 0.930 \\
\hline 2 & Sri Lanka & 19.75 & China & 16.14 & New Zealand & 0.901 \\
\hline 3 & India & 19.49 & Sri Lanka & 15.42 & Japan & 0.878 \\
\hline 4 & Pakistan & 18.30 & Pakistan & 15.02 & Korea & 0.863 \\
\hline 5 & Korea & 15.72 & India & 13.32 & Hong Kong & 0.852 \\
\hline 6 & Philippines & 11.46 & Philippines & 10.79 & Singapore & 0.835 \\
\hline 7 & Malaysia & 10.84 & Malaysia & 9.43 & Malaysia & 0.734 \\
\hline 8 & Singapore & 10.07 & Korea & 9.10 & China & 0.637 \\
\hline 9 & Thailand & 9.65 & Singapore & 7.24 & Sri Lanka & 0.645 \\
\hline 10 & Australia & 8.18 & Thailand & 7.19 & Thailand & 0.641 \\
\hline 11 & Hong Kong & 6.48 & Australia & 6.42 & Philippines & 0.628 \\
\hline 12 & China & 6.38 & New Zealand & 5.42 & Indonesia & 0.578 \\
\hline 13 & New Zealand & 3.13 & Hong Kong & 3.64 & India & 0.498 \\
\hline 14 & Japan & 0.69 & Japan & -0.06 & Pakistan & 0.478 \\
\hline
\end{tabular}

Overall, countries that have higher economic growth rates tend to have higher MSCI returns, although their rankings may not be the same under these two indicators. Interestingly, the 


\section{Macrothink}

sample countries with higher GDP growth, mainly from the less-developed group, tend to have lower HDI scores which implies that when a country improves its economic well-being, it tends to increase its financial wealth or vice a versa, at the cost of social well-being of people in that country. Sri Lanka, however, has been able to maintain a balance between financial, economic, and social development to a certain level.

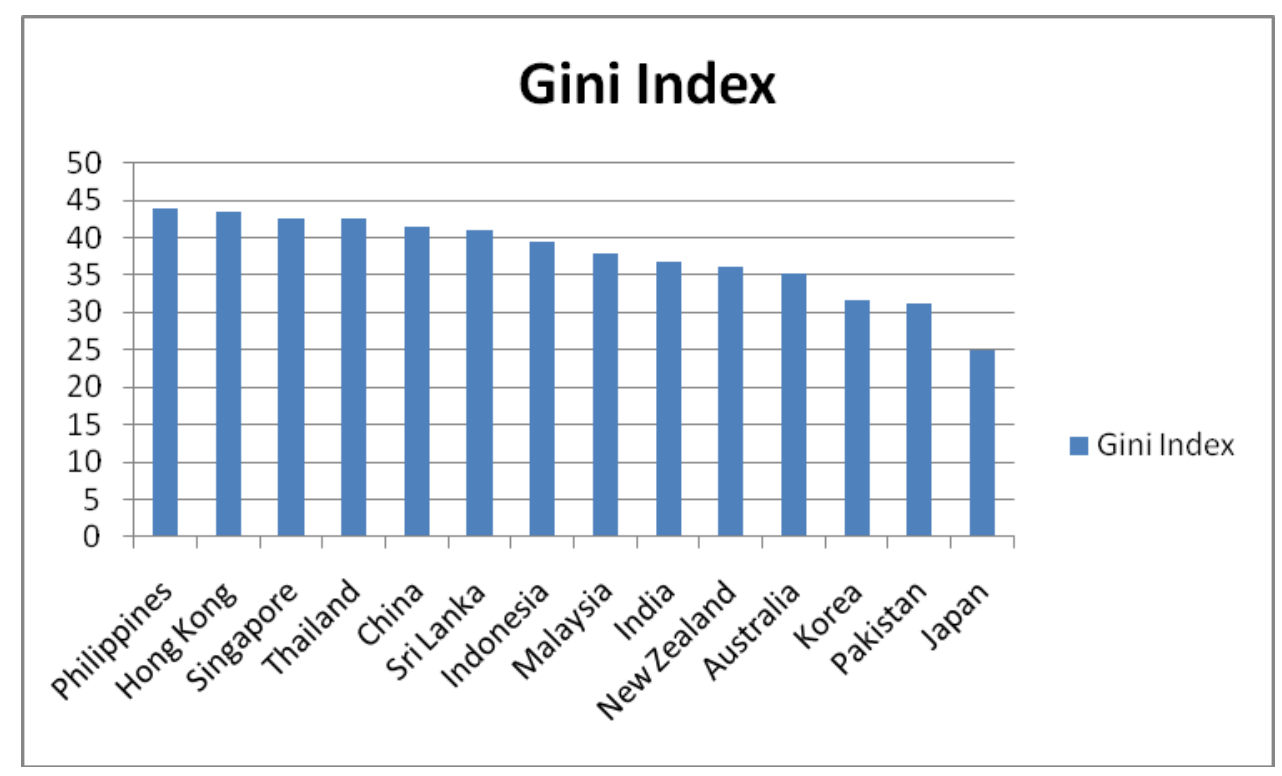

Graph 1. Gini Index (2007)

The Gini Index must, however, be interpreted with care. A lower ranking in Gini Index indicates lower income inequality, which is generally an economically as well as socially desirable condition. One may expect a country with a high Gini Index value (high income inequality) to have a lower score (lower transparency) in the CPI. The Philippines had the highest Gini Index among the sample countries (Graph 1), while Japan had the lowest index which is compatible with HDI data. As expected, the Philippines, a country with a high degree of income inequality, also had the low levels of transparency in the CPI. In fact, it was ranked the lowest (Graphs 2). 


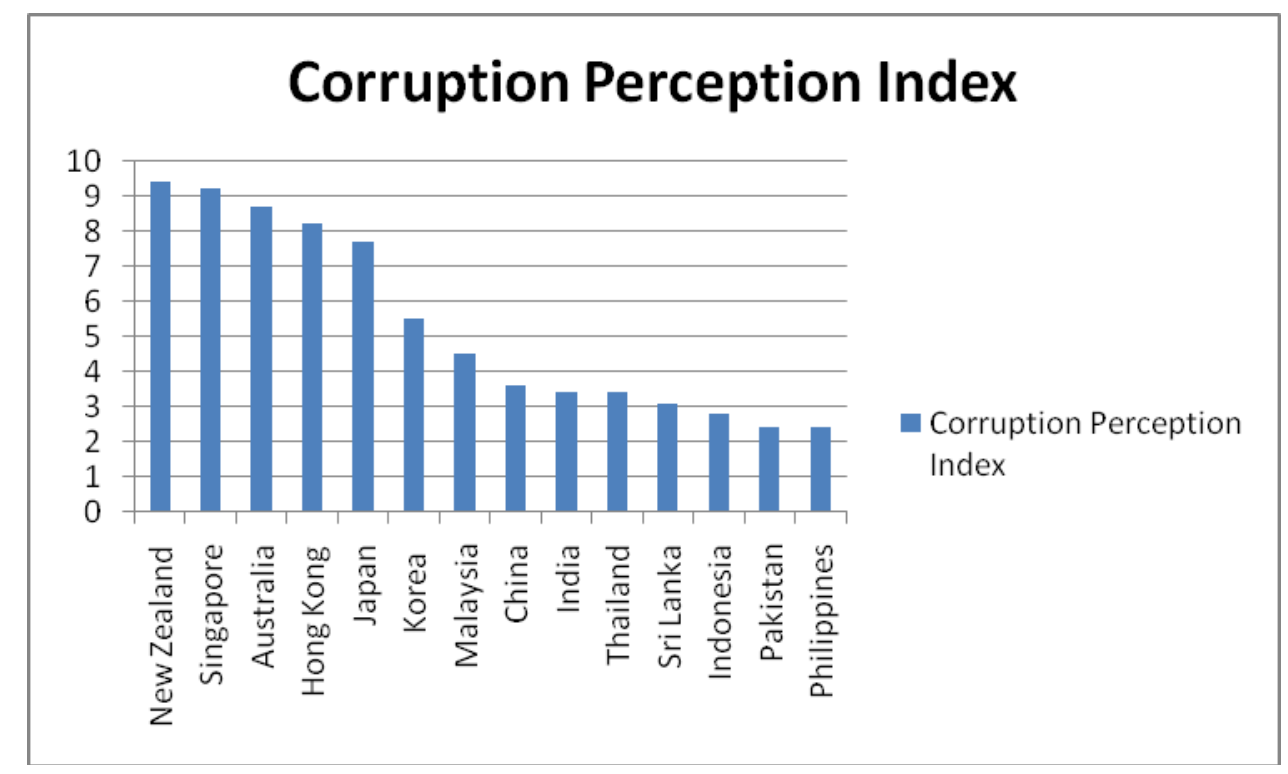

Graph 2. Corruption Perception Index (CPI) (2009)

However, this pattern of high level of inequality and low corruption perception does not hold true for all the countries. For instance, while Hong Kong and Singapore ranked high in the Gini Index (indicating high income inequality), their CPI rankings were also high (depicting low levels of corruption). The situation in Singapore can be explained by the government's severe penalty for corruption. Generally, the countries that rank low in the CPI are developing countries while countries with higher ranks are developed countries.

\subsubsection{Relationship between MSCI returns, GDP growth, and HDI}

Pearson and partial correlations between MSCI returns, nominal GDP growth, and HDI were analysed for the years 2005-2009. Gini Coefficient and CPI were not included due to unavailability of annual data. The results are presented in Table 5. 
Table 5. Correlations between Economic, Socioeconomic and Stock Market Performance (2005-2009)

\begin{tabular}{|c|c|c|c|c|c|c|c|c|c|}
\hline \multirow[t]{2}{*}{ Country } & \multicolumn{3}{|c|}{ MSCI Return and GDP } & \multicolumn{3}{|c|}{ MSCI Return and HDI } & \multicolumn{3}{|c|}{ HDI and GDP } \\
\hline & Pearson & Partial1 & Partial2 & Pearson & Partial1 & Partial2 & Pearson & Partial1 & Partial2 \\
\hline Australia & -.561 & -.647 & -.975 & -.244 & -.923 & .755 & -.510 & .891 & .883 \\
\hline China & -.018 & .981 & .962 & -.151 & -.239 & .336 & -.121 & -.422 & .065 \\
\hline Hong Kong & -.119 & .966 & .852 & .063 & -.470 & .862 & -.686 & -.682 & .469 \\
\hline India & .117 & $.996 *$ & .981 & -.027 & .546 & .762 & -.696 & .465 & .622 \\
\hline Indonesia & $-.930 *$ & -.882 & $.991^{*}$ & .029 & -.535 & -.637 & -.290 & .869 & .733 \\
\hline Japan & .155 & $1.00 * *$ & -.812 & $-.816^{*}$ & -.988 & $-1.00 * *$ & -.540 & -.987 & .819 \\
\hline Korea & -.258 & .451 & .008 & -.253 & -.772 & -.224 & -.049 & .219 & .828 \\
\hline Malaysia & -.697 & .972 & -.458 & .077 & .949 & .171 & -.368 & $.996 *$ & .797 \\
\hline New Zealand & -.672 & $-.990 *$ & -.202 & -.269 & -.728 & -.900 & -.510 & .622 & -.244 \\
\hline Pakistan & .294 & .310 & -.633 & -.049 & -.520 & -.300 & .579 & -.973 & -.549 \\
\hline Philippines & -.610 & .364 & .240 & -.140 & -.867 & -.846 & -.642 & -.780 & -.721 \\
\hline Singapore & -.142 & $1.00 * *$ & .692 & .003 & -.782 & .940 & -.552 & -.794 & .897 \\
\hline Sri Lanka & $-.965 * *$ & .983 & .142 & .253 & .951 & .063 & -.254 & $.991 *$ & $.997 *$ \\
\hline Thailand & -.517 & .983 & .774 & .135 & -.656 & $-.999 *$ & -.750 & -.505 & -.750 \\
\hline Developed & -.078 & $.479 *$ & $.540 * *$ & -.152 & -.152 & .034 & .013 & $-.616 * *$ & -.080 \\
\hline Emerging & -.103 & $.502 * *$ & $.343^{*}$ & -.130 & -.236 & -.305 & $-.544 * *$ & $-.524 * *$ & $-.485 * *$ \\
\hline Frontier & -.543 & .641 & .220 & .119 & $.772 *$ & .567 & -.075 & $.784 *$ & $.767 *$ \\
\hline All countries & -.007 & $.556^{* *}$ & $.487 * *$ & $-.201 *$ & $-.320 *$ & $-.422 * *$ & $-.666^{* *}$ & $-.462 * *$ & $-.540 * *$ \\
\hline $\begin{array}{l}\text { Partial } 1 \text { contr } \\
\text { MSCI classifi } \\
\text { India, Indones } \\
\text { * Significant }\end{array}$ & $\begin{array}{l}\text { ed for GD } \\
\text { tion: Dev } \\
\text { Korea, } N \\
\text { he } 0.05 \text { le }\end{array}$ & $\begin{array}{l}\text { Deflato } \\
\text { loped (A } \\
\text { laysia, } \mathrm{P} \\
\text { el (1-taile }\end{array}$ & $\begin{array}{l}\text { and Partia } \\
\text { stralia, H } \\
\text { ilippines, } \\
\text { d). ** Si }\end{array}$ & $\begin{array}{l}2 \text { control } \\
\text { g Kong, } \\
\text { hailand), } \\
\text { nificant a }\end{array}$ & $\begin{array}{l}\mathrm{d} \text { for Con } \\
\text { apan, Ne } \\
\text { rontier (P } \\
\text { he } 0.01 \text { l }\end{array}$ & $\begin{array}{l}\text { Imer Pric } \\
\text { Zealand, } \\
\text { kistan, Sri } \\
\text { el (1-taile }\end{array}$ & $\begin{array}{l}\text { Index. } \\
\text { Singapor } \\
\text { anka) }\end{array}$ & Emerg & ( China, \\
\hline
\end{tabular}

The results show that Indonesia and Sri Lanka had strongly and significantly negative correlations between MSCI returns and GDP growth. When controlled for inflation using the GDP deflator and the Consumer Price Index, India, Japan, China, Indonesia and Singapore showed perfect or near perfect positive partial correlations between MSCI returns and GDP growth, whereas New Zealand had a strongly and significantly negative correlation between these two variables. Japan and Thailand were found to have significant and negative relationships in their MSCI returns and HDI. On the other hand, Malaysia and Sri Lanka showed strong and positive relationships between HDI and GDP growth.

When the sample was grouped under MSCI country classification ${ }^{4}$, developed and emerging countries in the Asia Pacific were found to have strongly positive correlations between MSCI

\footnotetext{
${ }^{4}$ MSCI classification: Developed (Australia, Hong Kong, Japan, New Zealand, Singapore), Emerging ( China, India, Indonesia, Korea, Malaysia, Philippines, Thailand), Frontier (Pakistan, Sri Lanka).
} 
returns and GDP growth, while the relationships were negative between HDI and GDP. Frontier countries like Pakistan and Sri Lanka had strong positive relationships between HDI and GDP growth. The results for Pakistan further indicated a positive correlation between HDI and MSCI return. Overall, the correlation analysis clearly shows a tendency towards wealth maximisation and concentration in the developed and emerging countries and more wealth distribution for social welfare in frontier or less-developed countries.

\section{The Case of Sri Lanka}

Sri Lanka, which is geographically close to India and China, the two large, developing countries with exceptionally high growth rates in recent decades, is an emerging economy according to the IMF classification, has shown strong economic growth in recent years. This country has achieved a respectable rate of economic and social development despite the long-running and destructive internal war. Hence, special attention is paid to Sri Lanka in this paper.

Sri Lanka has a very high literacy rate of $91.3 \%$, one of the highest in the region. However, the dependency ratio is also high at 48.3\% (Central Bank of Sri Lanka Annual Report, 2009). Each year the Government of Sri Lanka spends a substantial portion of its national income on the social welfare programs such as free education, free public health, and both financial and non-financial assistance to the less-privileged members in the country. In the early 90's a new cohort of creative and strategically oriented entrepreneurs emerged, buoyed by an aggressive privatization program. Since then the economy of Sri Lanka has improved considerably, in large part due to investor-friendly policy measures such as dedicated FDI zones, expansion of infrastructure, the increasing number of skilled employees, and the opening up of the capital market to foreign investment; all of which contributed to economic growth. For instance, the number of foreign companies has visibly increased. In 1995 FDI was only $0.4 \%$ of GDP, however, by 2007 it had increased to over $2 \%$. Moreover, Sri Lanka's FDI is widely diversified and include: ceramics, rubber, electrical goods, gems and jewellery, information technology and business process outsourcing, education, tourism, agriculture, textile and apparel, fabricated metal, and the medical and pharmaceutical industries (Central Bank of Sri Lanka, 2008). At present, 70\% of exports from Sri Lanka and $80 \%$ of its industrial exports are carried out by companies approved by the Board of Investments.

As a result of the foregoing developments, Sri Lanka is now in a position to compete in the global market place. Although the devastating Boxing Day tsunami in 2004 may have set back some of these efforts, the end of three decades of civil war coupled with investor-friendly policies, have resulted in a large expansion of national and international business activities in Sri Lanka. According to United Nations Development Program (UNDP), in 2009 Sri Lanka’s per capita GDP was US\$ 2,029 (1 US\$ = SLRs. 110.80 on 31 October 2010), which increased to US\$4999 in the following year (UNDP, 2011).

The performance of Sri Lanka's economy depends heavily on the service sector, (claims 59\% of the GDP), the industrial sector (28.6\%) and the agriculture sector (12\%). While tea, rubber, coconut and some agricultural crops still play a major part in Sri Lanka's export profile, these commodities have been superseded by textile and clothing exports (Central Bank of Sri Lanka, 2009). 
The Colombo Stock Exchange (CSE) is Sri Lanka's major stock exchange and one of the most advanced stock exchanges in South Asia. The CSE has 232 companies representing 20 business sectors and the market capitalisation as of $31^{\text {st }}$ March 2010 was SLRs. 1,210.8 billion (US\$ 10.91 billion). For the years 1993-2009, Sri Lanka had a mean MSCI return of $19.75 \%$, with a wide range between $-60.58 \%$ and $187.67 \%$ as presented in Table 1 . During the same period, Sri Lanka experienced a satisfactory average GDP growth of $15.42 \%$, with a range between $8.64 \%$ and $23.25 \%$ (Table 1 ).

Sri Lanka was ranked one of the top two on both MSCI returns (21.39\%) and GDP growth rate (15.90\%) during the 1997 East Asian crisis. For the period immediately before, during and after the 1997 financial crisis (1996-1998), Sri Lanka's GDP growth rates stayed within 14.35 - 15.90\%. Although its MSCI returns were high (21.39\%) in 1997, the values were negative for the years before (-11.26\%) and after (-19.44\%), as presented in Table 2A.

During the 2007 global financial crisis, Sri Lanka's MSCI returns were also high and were ranked within the top three for the years 2006 and 2009, with returns of $50.26 \%$ and $187.67 \%$ in the respective years (Table 3A). However, in 2007 and 2008, with its negative MSCI returns of $-14.20 \%$ and $-60.58 \%$, respectively, Sri Lanka was ranked as second from the bottom. This shows that Sri Lanka, as well as most other open economies in the world, were adversely affected by the 2007 global financial crisis, but the data shows the stock market was able to recover itself by 2009. Although the drop in Sri Lanka's GDP growth from $23.25 \%$ (2008) to $9.40 \%$ (2009) may have resulted from the global financial crisis, the country maintained its rank in the top three for the GDP growth in the years 2006-2008 (Table 3B).

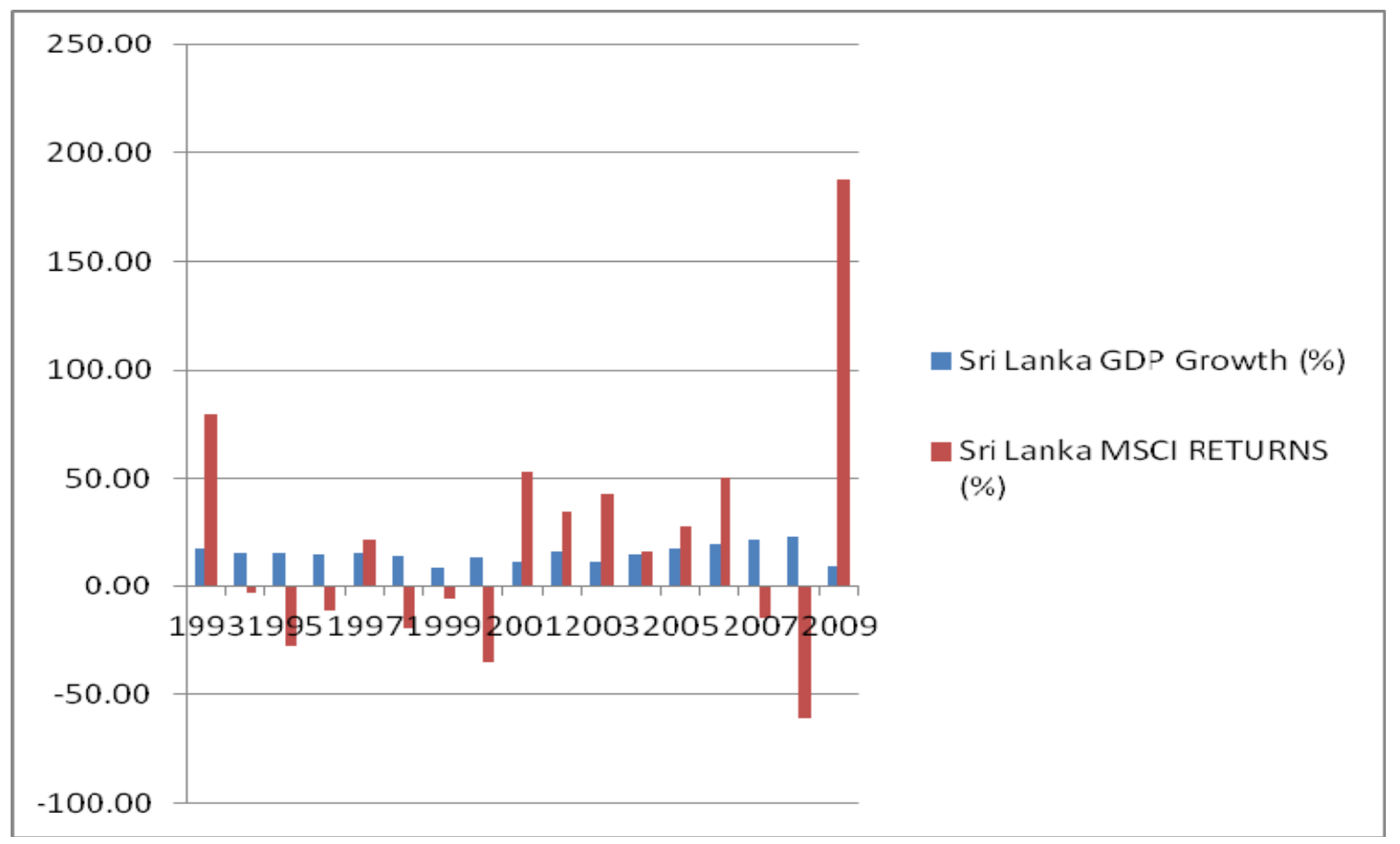

Graph 3. Sri Lanka’s GDP Growth and MSCI returns (1993-2009) 
During the entire sample period 1993-2009, Sri Lanka was, on average, ranked among the top three on both MSCI returns and GDP growth. Furthermore, the country sustained double-digit GDP growth rates except for the years 1999 and 2009. The country's MSCI returns were highly variable throughout the sample years, with $-60.58 \%$ in 2008 and $187.67 \%$ in 2009 (Graph 3). Concurrent to this, UNDP (2011) data on HDI shows continuous improvements in the health, safety, nutrition and education of its people suggesting Sri Lanka's commitment in social welfare.

Among the financial indicators in 2009, Sri Lanka occupied top rank on MSCI returns. It is worthwhile to note however, there were varying numbers of companies included each year for MSCI calculations. According to the CSE data, 231 companies with a total market capitalization of SLRs 1,092.1 billion (equivalent to US\$ 958 million at 1 US\$ = SLR 114) were listed on the CSE as of $31^{\text {st }}$ December 2009. The number of companies included in the MSCI for 2009 was only three. However, those few companies had an immense influence on the stock market in Sri Lanka by claiming over $80 \%$ of the total market capitalization (US\$ 767 million) (MSCI Barra). It is also interesting to note that there were no significant correlations between MSCI returns and HDI (Table 5) in Sri Lanka. As a possible future study it may be worthwhile investigating the relationship between the local market index and the HDI.

\section{Conclusion}

The purpose of this study was to investigate the movements among economic, financial and socio-economic indicators, and also to see whether MSCI returns, GDP growth, and HDI were positively correlated. The results show that MSCI returns and GDP growth rates were positively associated with each other in developed and emerging economies at the expense of social welfare. However, some frontier economies had been able to maintain a balance between economic and social performance.

The results also show that while most of the developing countries in the Asia-Pacific region such as India, Indonesia and Sri Lanka consistently scored high on financial and economic indicators. In contrary to this, Japan, an industrialized economy, ranked one of the lowest on financial and economic variables, while scoring high on HDI. There were similar rankings for certain countries in particular years, but the financial and economic variables did not always provide consistent rankings. The results also show that while most of the developing countries in the region have experienced rapid growth in total output, per capita incomes and capital markets, they may need to make further improvements in HDI by enhancing the following aspects: social welfare, income equality, employment rates, human capital, economic freedom, transparency and good governance.

More advanced statistical models and methods for testing hypotheses are necessary in order to obtain stronger results which can be done in subsequent studies. There is a need to carry out more research in the fields of economics, finance and social policy issues.

\section{References}

Albuquerque, R. and Vega, C. (2009). Economic news and international stock market 
co-movement, Review of Finance, 13: 401-465. http://dx.doi.org/10.1093/rof/rfn020

Alvan, A. (2009). Forging a link between human development and income inequality: cross-country evidence, Review of Social, Economic \& Business Studies, 7/8, 31-43

Central Bank of Sri Lanka. (2008). Annual report 2008.

Fifield, S.G.M., Power, D.M., and Sinclaire, C.D. (2002). Macroeconomic factors and share returns: an analysis using emerging market data, International Journal of Finance and Economics, 7: 51-62. http://dx.doi.org/10.1002/ijfe.173

Gunasekarage, A., Pisedtasalasai, A., and Power, D.M. (2004). Macroeconomic influence on the stock market: evidence from an emerging market in South Asia, Journal of Emerging market Finance, 3(3): 285-304. http://dx.doi.org/10.1177/097265270400300304

Gregory, P. and Stuart, R.C. (2004). Comparing Economic Systems in the Twenty-First Century, South Western Cengage Learning.

Handa, J. and Khan, S. R. (2008). Financial development and economic growth: a symbiotic relationship, Applied Financial Economics, 18, 1033-1049. http://dx.doi.org/10.1080/09603100701477275

Henry, Ó. T., Olekalns, N. and Thong, J. (2004). Do stock market returns predict changes to output? Evidence from a nonlinear panel data model, Empirical Economics, 29: 527-540. http://dx.doi.org/10.1007/s00181-003-0182-4

Johnson, R. and Soenen, L. (2002). Asian economic integration and stock market comovement, The Journal of Financial Research, 25(1): 141-157. http://dx.doi.org/10.1111/1475-6803.00009

International Monetary Fund. (2010 and Various Issues).World Economic Outlook.

Kyereboah-Coleman, A. and Agyire-Tettey, K. F., (2008). Impact of macroeconomic indicators on stock market performance: The case of the Ghana Stock Exchange, The Journal of Risk Finance, 9(4): 365-378. http://dx.doi.org/10.1108/15265940810895025

Lee, C. L., Boon, T. H., and Baharumshah, A. Z., (2001), The Stock Market, Macroeconomic Fundamentals, and Economic Growth in Malaysia, Asia Pacific Journal of Economics \& Business, 5 (2), 44-55

Patro, D.K., Wald, J.K., Wu, Y. (2002). The impact of macroeconomic and financial variables on market risk: evidence from international equity returns, European Financial Management, 8(4): 421-447. http://dx.doi.org/10.1111/1468-036X.00198

Pilinkus, D. (2009). Stock market and macroeconomic variables: Evidence from Lithuania, Economics and Management, 14: 884-891.

Rosser J.B. and Rosser M.V. (2004). Comparative Economics in a Transforming world Economy, The MIT Press, Cambridge, Massachusettes.

United Nations Development Program. (2011). International Human Development Indicators, 
http://hdr.undp.org, accessed: 7/20/2011

Wickremasinghe, G. (2011). The Sri Lankan stock market and the macroeconomy: an empirical investigation, Studies in Economics and Finance, 28(3): 179-195. http://dx.doi.org/10.1108/10867371111141954 